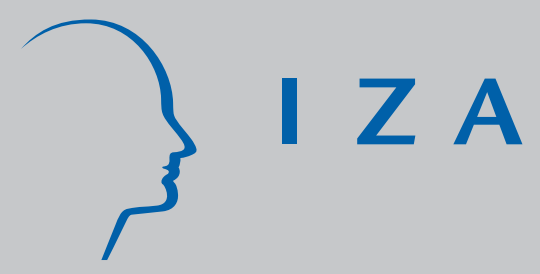

IZA DP No. 3788

North-South Trade Liberalization and Returns to Skill in the South: The Case of Mexico

Gautam Hazarika

Rafael Otero

October 2008 


\title{
North-South Trade Liberalization and Returns to Skill in the South: The Case of Mexico
}

\author{
Gautam Hazarika \\ University of Texas at Brownsville \\ and IZA \\ Rafael Otero \\ University of Texas at Brownsville
}

Discussion Paper No. 3788

October 2008

\author{
IZA \\ P.O. Box 7240 \\ 53072 Bonn \\ Germany \\ Phone: +49-228-3894-0 \\ Fax: +49-228-3894-180 \\ E-mail: iza@iza.org
}

\begin{abstract}
Any opinions expressed here are those of the author(s) and not those of IZA. Research published in this series may include views on policy, but the institute itself takes no institutional policy positions.

The Institute for the Study of Labor (IZA) in Bonn is a local and virtual international research center and a place of communication between science, politics and business. IZA is an independent nonprofit organization supported by Deutsche Post World Net. The center is associated with the University of Bonn and offers a stimulating research environment through its international network, workshops and conferences, data service, project support, research visits and doctoral program. IZA engages in (i) original and internationally competitive research in all fields of labor economics, (ii) development of policy concepts, and (iii) dissemination of research results and concepts to the interested public.
\end{abstract}

IZA Discussion Papers often represent preliminary work and are circulated to encourage discussion. Citation of such a paper should account for its provisional character. A revised version may be available directly from the author. 


\section{ABSTRACT}

\section{North-South Trade Liberalization and Returns to Skill in the South: The Case of Mexico}

This study examines the effect of NAFTA, an instance of North-South trade liberalization, on returns to skill in Mexico. Mexico is abundant in low-skill workers relative to the US and Canada, and so, by the Hecksher-Ohlin-Samuelson trade model, NAFTA ought to have raised the relative earnings of low-skill workers, that is, lowered returns to skill in Mexico. Analysis of Mexican labor micro-data yields the finding that while returns to skill in industries producing tradeables have risen, ceteris paribus, since Mexico embarked upon trade liberalization by joining the GATT in 1986, this rise was less pronounced by 1999 in industries liberalized relatively rapidly by NAFTA, launched in 1994, than in industries liberalized relatively slowly by this phased trade treaty. This is considered evidence of NAFTA holding back rise in returns to skill, since it is plausible such a dampening would have been more marked in industries more rapidly exposed to trade with Mexico's skill abundant northern neighbors. Hence, this study suggests trade with developed nations may lower returns to skill in developing nations. It is speculated this may slow the pace of private human capital accumulation in developing nations, with negative consequences for their economic growth.

JEL Classification: F11, I21

Keywords: $\quad$ NAFTA, Heckscher-Ohlin model, human capital

Corresponding author:

Gautam Hazarika

Department of Business Administration

The University of Texas at Brownsville

80 Fort Brown

Brownsville, TX 78520

USA

E-mail: gautam.hazarika@utb.edu 


\section{Introduction}

Neo-Classical theory contends international trade may alter returns to skill and, thereby, the distribution of earnings. Indeed, international trade is held by some to be the primary factor in widening earnings inequality in the U.S. (for example, Burtless 1995). The import from less developed countries, the South, of goods intensive in the use of low-skill workers has, it is argued, depressed these workers' earnings in developed countries, the North, thereby raising returns to skill and widening earnings inequality. By this argument, North-South trade ought to have raised the earnings of low-skill workers and, hence, reduced earnings inequality in the South. Consequently, this paper aims to contribute to the body of research examining the effect of the North American Free Trade Agreement (NAFTA), an instance of North-South trade liberalization, upon returns to skill in Mexico.

This is a worthy subject of study because it is distinctly possible that lowered returns to skill in the South upon the opening up of trade with the North shall hinder the South's ability to realize dynamic gains from trade, that is, international trade stimulated economic growth. Grossman and Helpman (1994) summarize the reasons why integration into the world economy is an important factor in national economic growth. First, a nation integrated into world markets enjoys access to a larger technical knowledge base than an autarky. Second, international competition forces domestic firms to be innovative rather than the merely imitative. Third, by expanding firms' customer base, economic integration raises the profitability of industrial research. It is likely these causal connections between international openness and economic growth hinge upon the availability of human capital, for a nation's ability to absorb new technologies from abroad increases in its stock of human capital (for example, Tybout 2000), and it is evident that industrial research and development is a human capital intensive endeavor. If rates of return to skill in developing countries were depressed upon the liberalization of trade with developed countries, developing countries would see a blunting of private incentives to accumulate human capital. With dampened private human capital accumulation, the capacities of developing countries to realize dynamic gains from trade may decline. As it is, the maximum dynamic gains attainable by developing nations are limited by the low-technology nature of the goods that static comparative advantage dictates they produce (for example, Young 1991). In addition, lowered private human capital accumulation may hold back national economic growth directly, that is, in ways unrelated to international trade (for example, Lucas 1988). 
Trade liberalization in Mexico may be said to have begun in earnest upon the Nation's joining the General Agreement on Tariffs and Trade (GATT) in 1986. A second momentous event in Mexico's history of trade liberalization was the launch of NAFTA in 1994. As described by Robertson (2004), the periods $1986-$ 1994 and 1994 - present are notably dissimilar in that the relative prices of skill-intensive goods in Mexico and, consequently, the relative earnings of skilled workers, rose between 1986 and 1994, but have fallen thereafter.

The Heckscher-Ohlin-Samuelson model predicts that trade based on comparative advantage shall lead to increases in the relative prices of goods intensive in the use of a nation's abundant resource and, therefore, to a rise in the relative price of this resource. Since it is commonly believed Mexico is abundant in low-skill workers, rise in the relative earnings of skilled workers, that is, fall in the relative earnings of low-skill workers in the period of trade liberalization preceding NAFTA is puzzling. Hanson and Harrison (1999) and, more successfully, Robertson (2000) contend that Mexico is really abundant in skilled workers in relation to the poorer nations that make up much of the world, and so a general liberalization of trade under the terms of the GATT in 1986 led to rise in the relative earnings of skilled workers. These authors present evidence that, prior to trade liberalization, Mexico protected its low-skill industries more than it did its high-skill industries and that liberalization under the GAT'T then caused tariffs upon the imports of low-skill goods to fall more rapidly than those upon the imports of high-skill goods. As a result, the relative prices of low-skill goods declined, causing decreases in the relative earnings of low-skill workers and, thus, widening wage inequality. NAFTA, however, was different in that it liberalized trade between Mexico and the more skill abundant United States and Canada. Therefore, argues Robertson (2004), the relative-prices of high-skill goods in Mexico have fallen since 1994, as, hence, have the relative earnings of high-skill workers. In sum, previous research indicates NAFTA lowered returns to skill in Mexico. It is the objective of this study to uncover, by means different, additional evidence of lowered returns to skill in the South upon the liberalization of its trade with the North. The principal differences between this study and previous such research are that it employs labor micro-data rather than data aggregated at the level of firms or industries, and, next, that its empirical strategy exploits the fact that NAFTA liberalized trade in some goods faster than trade in others.

The remainder of the paper is organized as follows. Section II discusses the empirical strategy. Section III describes the data, and presents and interprets the empirical findings. Section IV summarizes these findings and presents the study's conclusions. 


\section{Empirical Strategy}

NAFTA began liberalizing trade between Mexico and its northern neighbors in 1994. This liberalization was a phased process in that some industries experienced a more rapid reduction in import tariffs than others. For example, tariffs on some goods were eliminated immediately, that is, in 1994, whereas imports of other goods were to become duty-free only by 1998 or later. In addition, some industries were unaffected by NAFTA, or largely so. Industries producing non-tradeables were naturally beyond the scope of NAFTA, those producing such supply-managed goods ${ }^{1}$ as milk, poultry, and eggs, were deliberately excluded from NAFTA, and this Preferential Trading Arrangement may have had little effect on Mexico’s maquiladora industry.

The Mexican government founded a border industrialization program in 1965 in order to combat unemployment in the border region resulting from the US's termination of the bracero program ${ }^{2}$ in 1964 . This industrialization program allowed the unrestricted entry of foreign capital into the border region. Manufactured goods were to be assembled by cheap Mexican labor from components originating in the United States, for reexport to the United States. Raw materials imported into Mexico were exempted from import duties and U.S. tariffs upon the import of the finished goods were to be levied only on Mexican value added. This policy resulted in the proliferation, by means of mostly U.S. capital, of export oriented manufacturing units, called maquiladoras 3 , along Mexico’s 2,000- mile northern border. Since U.S. import tariffs were levied only upon the Mexican value-added portion of the output of maquiladoras, consisting often of the modest value-added by mere assembly of U.S. components, tariffs upon these goods were low to begin with, and so NAFTA is unlikely to have significantly eased U.S. imports of maquiladora output. Indeed, even though tariff reduction under NAFTA was extended to maquiladoras, the phased nature of tariff reduction implied U.S. import tariffs in the maquiladora program may, in the beginning, have been lower than under NAFTA (Gruben 2001).

In sum, it is possible to distinguish between four sectors of the Mexican economy: the sector producing non-tradeables and the few supply-managed tradeables excluded from NAFTA, untouched by this Preferential Trading Arrangement, the maquiladora sector, perhaps only marginally affected by NAFTA, the sector producing goods the imports of which were liberalized relatively slowly under NAFTA, and the sector producing items the imports of which were liberalized relatively rapidly. It is plausible the first two sectors

\footnotetext{
1 goods whose domestic supply is restricted so as to raise their prices, ostensibly to benefit their producers 2 The bracero program was instituted on August 4, 1942, to alleviate a manual labor shortage in the U.S. on account of the war.

3 The term derives from the Spanish verb maquilar, which means 'to put together or assemble'.
} 
were largely unaffected as well by Mexico's joining the GATT in 1986, since the first produces mainly nontradeables, NAFTA's exclusions being few, and the GATT resulted mainly in sharp reductions in Mexican import duties whereas the maquiladora sector, using raw materials imported duty-free, is entirely exportoriented. Might differences between these sectors' time-trends in rates of return to schooling enable identification of the effect of NAFTA, an instance of North-South trade liberalization, upon returns to skill in Mexico?

Liberalized North-South trade shall bring about rise in the relative prices of low-skill goods in the South, expansion of the South's low-skill industries, a rise in demand for low-skill workers, and, hence, depression in returns to skill, holds Neo-Classical theory. Might this occur faster in the sectors of Southern economies more rapidly exposed to trade with the North? Note that differences between sectors in time-trends in returns to skill may make for inter-sectoral differences, inconsistent with Neo-Classical theory, in the compensation of identical workers at a point in time. However, such differences become plausible in a world of industry rents.

Protected industries enjoy rents (Revenga 1997), and so, prior to NAFTA, high-skill industries in Mexico enjoyed rents in relation to these industries in the U.S. and Canada, whereas low-skill industries in the U.S. and Canada enjoyed rents compared with these industries in Mexico. Such rents may be passed on to workers (Revenga 1997). It is conceivable that rents shall make up a larger share of the compensation of a skilled worker than of the compensation of a low-skill worker in high-skill industries, since their superior numbers in these industries may endow skilled workers with greater bargaining power over the division of rents. Similarly, it is plausible that rents shall constitute a larger share of the compensation of a low-skill worker than of the compensation of a skilled worker in low-skill industries. Consequently, the whittling down of rents in Mexico's high-skill industries by the import competition effected by NAFTA would have hurt Mexican high-skill workers more than low-skill workers. Similarly, the capture by Mexico's low-skill industries of part of the rents of the U.S.'s and Canada's low-skill industries, facilitated by NAFTA, would have benefited Mexico's low-skill workers more than its high-skill workers. A fall in measured returns to skill would have resulted. Now, consider, for simplicity, two sectors of the Mexican economy, each consisting of a mix of high and low skill industries. Say, one was more rapidly exposed to trade with the U.S. and Canada under NAFTA's phased tariff elimination than the other. It is conceivable that the process described above whereby returns to 
skill are depressed would occur faster in the more speedily liberalized sector. This logic is the basis of this study's empirical strategy.

Recall that it is possible to distinguish between four sectors of the Mexican economy: the sector producing non-tradeables and goods excluded from NAFTA, untouched by this tripartite treaty, the maquiladora sector, perhaps only slightly affected by NAFTA, the sector producing goods the imports of which were liberalized relatively slowly under NAFTA, and the sector producing items the imports of which were liberalized relatively rapidly. Consider the two years 1987 and 1999. The former marks the beginnings of Mexican trade liberalization under the GATT but precedes the launch of NAFTA by some 7 years. The latter marks the complete elimination of tariffs under NAFTA for some, though not all industries. Imports of goods exempted from duties by 1999 under the terms of NAFTA may be considered relatively rapidly liberalized by this Preferential Trading Arrangement, whereas imports of goods yet subject to tariffs by 1999 may be deemed relatively slowly liberalized. Consider, now, the Mincer earnings function, fitted to labor micro-data from the years 1987 and 1999,

$$
\begin{aligned}
& \ln (\text { monthly earnings })=\mathbf{a}+X^{\prime} \mathbf{b} \\
& \left.+\sum_{\mathrm{j}} \mathbf{c}_{1 j} \cdot \text { (years of schooling } \times \text { industry } j\right)+\sum_{\mathrm{j}} \mathbf{c}_{2 j} \cdot(\text { years of schooling } \times \text { industry } j \times \text { year 1999) } \\
& \left.+\mathbf{d}_{\mathbf{1}} \cdot \text { (years of schooling } \times \text { maquila }\right)+\mathbf{d}_{2} \text {. (years of schooling } \times \text { maquila } \times \text { year 1999) } \\
& \left.\left.+\mathbf{e}_{1} \cdot \text { (years of schooling } \times \text { fastlib }\right)+\mathbf{e}_{2} \text {. (years of schooling } \times \text { fastlib } \times \text { year } 1999\right) \\
& +\mathbf{f}_{1} \cdot(\text { years of schooling } \times \text { slowlib })+\mathbf{f}_{2} \cdot(\text { years of schooling } \times \text { slowlib } \times \text { year 1999 })+u
\end{aligned}
$$

where $X$ represents a vector of influences, including personal and environmental characteristics, upon a worker's monthly earnings, industry $j$ signifies employment in industrial class $j$ (farm, manufacturing, commerce, etc.), maquila denotes employment in the maquiladora sub-sector of manufacturing, fastlib indicates employment in industries producing goods exempted from tariffs by 1999 under the terms of NAFTA, slowlib indicates employment in industries producing goods yet subject to tariffs by 1999 , and $u$ signifies unobserved random influences upon the worker's log monthly earnings. As is well known, the coefficient of years of schooling in a Mincer earnings function measures the rate of return to schooling, that is, the percentage increase in earnings from an additional year of schooling, a common metric of returns to skill.

This specification of the Mincer earnings function permits rates of return to schooling in 1987 as well as changes in these between 1987 and 1999 to differ between broad industrial classes. Industries within these classes that produce tradeables, with the exception of the few excluded from NAFTA, are indicated by the 
variables fastlib and slowlib ${ }^{4}$, and so changes in rates of return to schooling between 1987 and 1999 measured by the coefficients $\mathbf{e}_{2}$ and $\mathbf{f}_{2}$ may be considered to originate in Mexican trade liberalization. These are, clearly, changes in addition to those measured by the coefficients $\mathbf{c}_{2 j}$ which may, hence, be considered largely secular, that is, unrelated to trade liberalization, originating, for example, in skill-biased technical progress.

The coefficient $\mathbf{d}_{2}$ measures change between 1987 and 1999, in addition to that measured by the particular $\mathbf{c}_{2 j}$ relevant to the industrial class of manufacturing, in the rate of return to schooling of maquiladora workers. As argued, it is likely Mexican trade liberalization under both the GATT and NAFTA had little bearing on the prospects of maquiladoras since U.S. import tariffs on the output of maquiladoras were low even prior to NAFTA and the principal effect of Mexico's joining the GATT was greatly lowered Mexican import duties whereas maquiladoras, using raw material s imported duty-free, are entirely export-oriented. Thus, it is plausible that the change measured by $\mathbf{d}_{2}$ resulted mainly from factors other than trade liberalization, such as skill-biased technical progress. Note that maquiladoras embody foreign direct investment and there is evidence such investment facilitates the transfer of technology across borders (Zhiqiang 2008). Further, there is evidence that firms producing for export markets embrace new technologies faster than firms focused on domestic markets (Robertson 2000). Thus, skill-biased technical progress in the maquiladora sector may have been more rapid than in the rest of manufacturing, and so it is conceivable that $\mathbf{d}_{2}>\mathbf{0}$.

As argued, changes in rates of return to schooling between 1987 and 1999 measured by the coefficients $\mathbf{e}_{2}$ and $\mathbf{f}_{2}$ may be taken to originate in the liberalization of trade. If the GATT eased imports into Mexico of low-skill goods from less developed nations more abundant in low-skill workers, and so hurt Mexico's low-skill industries more than its skill-intensive industries with the result that returns to skill were elevated, this trade treaty will have resulted in both $\mathbf{e}_{2}$ and $\mathbf{f}_{2}$ taking positive values. However, if NAFTA, liberalizing trade between Mexico and the more skill-abundant U.S. and Canada, has reversed these earlier increases in returns to skill (Robertson 2004), this reversal, by the logic set forth in this study, will have been more pronounced by 1999 in the sector, fastlib, producing goods the imports of which were liberalized relatively rapidly under NAFTA, than in the sector, slowlib, producing goods the imports of which were liberalized relatively slowly, leading to $\mathbf{e}_{2}<\mathbf{f}_{2}$. If the decline in returns to skill owing to NAFTA has more than offset the

\footnotetext{
${ }^{4}$ While the labels fastlib and slowlib pertain to NAFTA, they really mark all tradeables but for the few excluded from the provisions of this tripartite treaty, and so the industries thus labeled would've been affected by both the GATT and NAFTA.
} 
rise in returns to skill brought about by GATT even in the more slowly liberalized sector, it would be that $\mathbf{e}_{2}<$ $\mathbf{f}_{2}<0$.

In sum, whether NAFTA, an instance of North-South trade liberalization, has depressed returns to skill in Mexico may be ascertained via a statistical test of the hypothesis $\mathbf{e}_{2}<\mathbf{f}_{2}$. It may be seen that this paper differs in two ways from previous studies of the impact of trade liberalization upon returns to skill in Mexico such as by Hanson and Harrison (1999), Robertson (2000), Robertson (2004), and Mollick (2008): it bases identification upon the phased nature of NAFTA, that is, the fact that this trade treaty liberalized trade in some goods faster than trade in others, and it employs labor micro-data ${ }^{5}$ rather than data aggregated at the level of firms or industries.

\section{The Data and Empirical Findings}

The Encuesta National de Empleo Urbano (ENEU), or National Urban Employment Survey, from the years 1987 and 1999 furnishes the data upon which this study's empirical analysis is based. As discussed, 1987 marks the beginnings of Mexican trade liberalization under the GATT but precedes the launch of NAFTA by some 7 years, whereas 1999 marks the complete elimination of tariffs under NAFTA for some, though not all industries. The ENEU supplies a quarterly data series rich in socio-economic information. In order to avoid excessively large, unwieldy sample sizes, the study uses data from but the $2^{\text {nd }}$ quarters of the 1987 and 1999 ENEU. The ENEU samples from about $60 \%$ of the nation's urban population including about $90 \%$ of the population in areas with 100,000 or more inhabitants, and so the data are representative of urban Mexico. A sample of 203,550 workers is yielded.

Table 1 presents the full definitions of the variables included in the analysis. Table 2 presents the sample mean values of these variables. Sample mean monthly earnings are approximately $1,564\left(\mathrm{e}^{7.355}\right)$ pesos whereas mean weekly hours worked are about $41\left(\mathrm{e}^{3.718}\right)$ hours. Approximately $38 \%$ of these workers were female. Since the geographical scope of this survey has greatly increased over time, it is not surprising that substantially more of these workers are drawn from the 1999 than from the 1987 ENEU. Sample mean years of schooling are a little over 9 . About $3.4 \%$ of these 203,550 workers are employed in the maquiladora subsector of manufacturing, about $2.6 \%$ in the sector producing goods the imports of which were liberalized relatively rapidly by NAFTA, and about $10.9 \%$ in the sector producing goods the imports of which were

\footnotetext{
${ }^{5}$ Robertson $(2000,2004)$ too uses labor micro-data, though for the purposes of basic illustration.
} 
liberalized relatively slowly by the terms of this Preferential Trading Arrangement, with the remainder engaged in sectors producing non-tradeables and the few supply-managed goods excluded from NAFTA.

Table 3 presents OLS estimates of the Mincer earnings function (1). As expected, log monthly earning increases in weekly hours worked. In keeping with human capital theory, log monthly earning significantly increases in years of work experience. Ceteris paribus, women earn less than men. Married workers, entrepreneurs, and those employed in the formal sector of the economy earn significantly more than others. It appears workers in micro (1 - 5 employees) firms earn less than the solitary self-employed, whereas those in small (6 - 50 employees), medium (51 - 250 employees), and large (more than 250 employees) firms earn more. It is indicated that workers in the border (with the US) region and in the northern region excluding the border region earn more, whereas workers in the nation's southern region earn less, than workers in the central region. By these estimates, the rate of return to schooling in the services sector, one producing non-tradeables, was $2.4 \%$ in 1987.

It may be noted that despite the concentration of foreign direct investment in maquiladoras and these firms' export-orientation, factors credited with speeding the rate of skill-biased technical progress, the statistical insignificance of the interaction schooling $\times$ maquila $\times$ year 1999 suggests that increase between 1987 and 1999 in the rate of return to schooling in maquiladoras was not greater than in the rest of manufacturing.

That the estimated coefficients of schooling $\times$ fastlib $\times$ year 1999 and schooling $\times$ slowlib $\times$ year 1999 are positive with the variables significant is consistent with previous findings (for example, Hanson and Harrison, 1999, and Robertson, 2000) of a positive effect upon returns to skill of Mexico's joining the GATT in 1986. It may be noted, however, that rise in returns to skill is less pronounced in industries producing tradeables the imports of which were liberalized more rapidly by NAFTA than in industries producing goods the imports of which were liberalized relatively slowly: the estimated coefficient of schooling $\times$ fastlib $\times$ year 1999 is smaller than that of schooling $\times$ slowlib $\times$ year 1999 with the difference significant at the $1 \%$ level. As argued, the above may be taken as indicative of a reversal, owing to NAFTA, of the GATT induced rise in returns to skill, a reversal more marked in the sector more rapidly liberalized by this phased trade treaty. In other words, this finding supports the view (e.g., Robertson, 2004) that NAFTA has lowered rates of return to skill in Mexico. NorthSouth trade liberalization may, then, lower rates of return to skill in the South. Finally, since the rate of return to schooling appears to have risen in net even in the more slowly liberalized sector, it does not appear that NAFTA has offset the rise in returns to skill from Mexico's joining the GATT. 


\section{Conclusion}

This study exploits the phased nature of tariff reductions under NAFTA to attempt identification of the effect of this instance of North-South trade liberalization upon returns to skill, measured as rates of return to schooling, in Mexico. It is held that Mexico’s joining the GAT'T in 1986 raised its workers' returns to skill whereas NAFTA has reversed this trend (for example, Robertson 2004). This study uncovers evidence from Mexican labor micro-data consistent with this view. It is found that while returns to skill in industries producing tradeables have risen, ceteris paribus, since Mexico embarked upon trade liberalization by joining the GATT in 1986, rise in returns to skill was less pronounced by 1999 in industries producing goods the imports of which were liberalized relatively rapidly by NAFTA, launched in 1994, than in industries producing goods the imports of which were liberalized relatively slowly by this phased tripartite treaty. This is taken to be due to NAFTA reversing the preceding increase in returns to skill from Mexico's joining GATT, since it is plausible this reversal was of greater magnitude in the sector producing goods the imports of which were liberalized relatively rapidly by NAFTA. Hence, this study suggests trade with developed nations may lower returns to skill in developing nations. It is speculated this may slow the pace of private human capital accumulation in developing nations, with negative consequences for their economic growth. 
TABLE 1 Definitions of Variables

\begin{tabular}{|c|c|}
\hline Variable & Definition \\
\hline log earnings & natural log of monthly earnings in 1999 pesos \\
\hline $\log$ hours & natural log of hours worked during week prior to interview \\
\hline experience & years of work experience (age - schooling - 6) \\
\hline female & $=1$ if female \\
\hline married & $=1$ if married \\
\hline formal & $=1$ if employed in formal sector \\
\hline owner & $=1$ if entrepreneur \\
\hline year 1999 & $=1$ if drawn from the 1999 ENEU \\
\hline $\begin{array}{l}\text { micro (firm size; omitted category is 'self- } \\
\text { employed with no employees') }\end{array}$ & $=1$ if employed in a firm with $1-5$ employees \\
\hline small (firm size) & $=1$ if employed in a firm with $6-50$ employees \\
\hline medium (firm size) & $=1$ if employed in a firm with $51-250$ employees \\
\hline large (firm size) & $=1$ if employed in a firm with more than 250 employees \\
\hline $\begin{array}{l}\text { border (region; omitted category is 'central } \\
\text { region') }\end{array}$ & $=1$ if lives on the Mexico - US border \\
\hline north (region) & $=1$ if lives in a northern state of Mexico not bordering the US \\
\hline south (region) & $=1$ if lives in a southern state of Mexico \\
\hline $\begin{array}{l}\text { professional (occupation; omitted category } \\
\text { is 'laborer') }\end{array}$ & $=1$ if a professional \\
\hline technical (occupation) & $=1$ if a technician \\
\hline managerial (occupation) & $=1$ if a manager \\
\hline $\begin{array}{l}\text { farm (industrial class; omitted category is } \\
\text { 'services') }\end{array}$ & $=1$ if employed in agricultural sector, including agro-based industry \\
\hline mine or electric (industrial class) & $=1$ if employed in mining or power sectors \\
\hline manufacturing (industrial class) & $=1$ if employed in the manufacturing sector \\
\hline construction (industrial class) & $=1$ if employed in the construction sector \\
\hline commerce (industrial class) & $=1$ if employed in the commerce sector \\
\hline maquila & $=1$ if employed in the maquiladora sub-sector of manufacturing \\
\hline fastlib & $\begin{array}{l}=1 \text { if employed in a sector, excluding the maquiladora sub-sector, with } \\
100 \% \text { tariff reduction by } 1999 \text { under NAFTA }\end{array}$ \\
\hline slowlib & $\begin{array}{l}=1 \text { if employed in a sector, excluding the maquiladora sub-sector, with } \\
\text { less than a } 100 \% \text { tariff reduction by } 1999 \text { under NAFTA }\end{array}$ \\
\hline farm $\times$ year 1999 & interaction of farm and year 1999 \\
\hline mine or electric $\times$ year 1999 & interaction of mine or electric and year 1999 \\
\hline manufacturing $\times$ year 1999 & interaction of manufacturing and year 1999 \\
\hline construction $\times$ year 1999 & interaction of construction and year 1999 \\
\hline commerce $\times$ year 1999 & interaction of commerce and year 1999 \\
\hline maquila $\times$ year 1999 & interaction of maquila and year 1999 \\
\hline fastlib $\times$ year 1999 & interaction of fastlib and year 1999 \\
\hline slowlib $\times$ year 1999 & interaction of slowlib and year 1999 \\
\hline schooling & years of formal education \\
\hline schooling $\times$ farm & interaction of schooling and farm \\
\hline schooling $\times$ mine or electric & interaction of schooling and mine or electric \\
\hline schooling $\times$ manufacturing & interaction of schooling and manufacturing \\
\hline schooling $\times$ construction & interaction of schooling and construction \\
\hline
\end{tabular}


TABLE 1 Definitions of Variables (continued)

\begin{tabular}{|l|l|}
\hline schooling $\times$ commerce & interaction of schooling and commerce \\
\hline schooling $\times$ maquila & interaction of schooling and maquila \\
\hline schooling $\times$ fastlib & interaction of schooling and fastlib \\
\hline schooling $\times$ slowlib & interaction of schooling and slowlib \\
\hline schooling $\times$ year 1999 & interaction of schooling and year 1999 \\
\hline schooling $\times$ farm $\times$ year 1999 & interaction of schooling, farm, and year 1999 \\
\hline schooling $\times$ mine or electric $\times$ year 1999 & interaction of schooling, mine or electric, and year 1999 \\
\hline schooling $\times$ manufacturing $\times$ year 1999 & interaction of schooling, manufacturing, and year 1999 \\
\hline schooling $\times$ construction $\times$ year 1999 & interaction of schooling, construction, and year 1999 \\
\hline schooling $\times$ commerce $\times$ year 1999 & interaction of schooling, commerce, and year 1999 \\
\hline schooling $\times$ maquila $\times$ year 1999 & interaction of schooling, maquila, and year 1999 \\
\hline schooling $\times$ fastlib $\times$ year 1999 & interaction of schooling, fastlib, and year 1999 \\
\hline schooling $\times$ slowlib $\times$ year 1999 & interaction of schooling, slowlib, and year 1999 \\
\hline
\end{tabular}


TABLE 2 Sample Statistics

$(\mathrm{n}=203,550)$

\begin{tabular}{|c|c|c|}
\hline Variable & Mean & S.D. \\
\hline log earnings & 7.355 & 1.684 \\
\hline $\log$ hours & 3.718 & 0.422 \\
\hline experience & 18.229 & 13.248 \\
\hline female & 0.375 & 0.484 \\
\hline married & 0.600 & 0.490 \\
\hline formal & 0.791 & 0.407 \\
\hline owner & 0.257 & 0.437 \\
\hline year 1999 & 0.793 & 0.405 \\
\hline micro (firm size) & 0.250 & 0.433 \\
\hline small (firm size) & 0.177 & 0.382 \\
\hline medium (firm size) & 0.070 & 0.255 \\
\hline large (firm size) & 0.354 & 0.478 \\
\hline border (region) & 0.124 & 0.329 \\
\hline north (region) & 0.399 & 0.490 \\
\hline south (region) & 0.141 & 0.348 \\
\hline professional (occupation) & 0.096 & 0.294 \\
\hline technical (occupation) & 0.042 & 0.200 \\
\hline managerial (occupation) & 0.115 & 0.319 \\
\hline farm (industrial class) & 0.016 & 0.126 \\
\hline mine or electric (industrial class) & 0.013 & 0.115 \\
\hline manufacturing (industrial class) & 0.227 & 0.419 \\
\hline construction (industrial class) & 0.058 & 0.233 \\
\hline commerce (industrial class) & 0.200 & 0.400 \\
\hline maquila & 0.034 & 0.182 \\
\hline fastlib & 0.026 & 0.160 \\
\hline slowlib & 0.109 & 0.312 \\
\hline farm $\times$ year 1999 & 0.013 & 0.112 \\
\hline mine or electric $\times$ year 1999 & 0.010 & 0.100 \\
\hline manufacturing $\times$ year 1999 & 0.171 & 0.377 \\
\hline construction $\times$ year 1999 & 0.046 & 0.209 \\
\hline commerce $\times$ year 1999 & 0.161 & 0.367 \\
\hline maquila $\times$ year 1999 & 0.025 & 0.157 \\
\hline fastlib $\times$ year 1999 & 0.146 & 0.353 \\
\hline slowlib $\times$ year 1999 & 0.361 & 0.480 \\
\hline schooling & 9.340 & 4.446 \\
\hline schooling $\times$ farm & 0.119 & 1.078 \\
\hline schooling $\times$ mine or electric & 0.150 & 1.391 \\
\hline schooling $\times$ manufacturing & 1.985 & 4.084 \\
\hline schooling $\times$ construction & 0.430 & 2.017 \\
\hline schooling $\times$ commerce & 1.802 & 4.025 \\
\hline schooling $\times$ maquila & 0.297 & 1.713 \\
\hline schooling $\times$ fastlib & 2.215 & 5.051 \\
\hline schooling $\times$ slowlib & 4.084 & 5.340 \\
\hline
\end{tabular}


TABLE 2 Sample Statistics (continued)

$(n=203,550)$

\begin{tabular}{|l|l|l|}
\hline schooling $\times$ year 1999 & 7.567 & 5.567 \\
\hline schooling $\times$ farm $\times$ year 1999 & 0.096 & 0.979 \\
\hline schooling $\times$ mine or electric $\times$ year 1999 & 0.116 & 1.240 \\
\hline schooling $\times$ manufacturing $\times$ year 1999 & 1.536 & 3.730 \\
\hline schooling $\times$ construction $\times$ year 1999 & 0.351 & 1.847 \\
\hline schooling $\times$ commerce $\times$ year 1999 & 1.481 & 3.748 \\
\hline schooling $\times$ maquila $\times$ year 1999 & 0.225 & 1.515 \\
\hline Key Variables & & \\
\hline schooling $\times$ fastlib $\times$ year 1999 & 1.746 & 4.633 \\
\hline schooling $\times$ slowlib $\times$ year 1999 & 3.348 & 5.149 \\
\hline
\end{tabular}


TABLE 3 Determinants of Log Monthly Earnings Dependent Variable = log earnings, OLS Estimates

\begin{tabular}{|c|c|c|}
\hline Variable & Coefficient & T-Ratio \\
\hline constant & $2.632^{* * *}$ & 67.29 \\
\hline $\log$ hours & $1.027 * * *$ & 133.02 \\
\hline experience & $0.005^{* * *}$ & 16.27 \\
\hline female & $-0.311 * * *$ & -45.9 \\
\hline married & $0.066^{* * *}$ & 9.78 \\
\hline formal & $0.068^{* * *}$ & 6.47 \\
\hline owner & $1.095^{* * *}$ & 113.25 \\
\hline year 1999 & $-0.195^{* * *}$ & -6.99 \\
\hline micro (firm size) & $-0.444 * * *$ & -37.41 \\
\hline small (firm size) & $0.815^{* * *}$ & 55.32 \\
\hline medium (firm size) & $1.035^{* * *}$ & 58.11 \\
\hline large (firm size) & $1.207 * * *$ & 81.2 \\
\hline border (region) & $0.383 * * *$ & 32.8 \\
\hline north (region) & $0.153^{* * *}$ & 21.18 \\
\hline south (region) & $-0.065^{* * *}$ & -7.04 \\
\hline professional (occupation) & $0.586^{* * *}$ & 43.81 \\
\hline technical (occupation) & $0.289^{* * *}$ & 18.55 \\
\hline managerial (occupation) & $0.593^{* * *}$ & 55.36 \\
\hline farm (industrial class) & $-0.946^{* * *}$ & -9.71 \\
\hline mine or electric (industrial class) & -0.194 & -1.46 \\
\hline manufacturing (industrial class) & -0.060 & -1.44 \\
\hline construction (industrial class) & $0.273^{* * *}$ & 4.72 \\
\hline commerce (industrial class) & $-1.016^{* * *}$ & -23 \\
\hline maquila & $-0.494 * * *$ & -5.43 \\
\hline fastlib & $-0.152 * * *$ & -7.05 \\
\hline slowlib & $-0.165^{* * *}$ & -11.92 \\
\hline farm $\times$ year 1999 & $-0.574^{* * *}$ & -5.13 \\
\hline mine or electric $\times$ year 1999 & 0.019 & 0.12 \\
\hline manufacturing $\times$ year 1999 & $-0.229 * * *$ & -4.89 \\
\hline construction $\times$ year 1999 & $0.183^{* * *}$ & 2.76 \\
\hline commerce $\times$ year 1999 & $0.253^{* * *}$ & 4.91 \\
\hline maquila $\times$ year 1999 & 0.023 & 0.22 \\
\hline fastlib $\times$ year 1999 & $-0.146^{* * *}$ & -5.66 \\
\hline slowlib $\times$ year 1999 & $-0.304 * * *$ & -13.62 \\
\hline schooling & $0.024 * * *$ & 8.32 \\
\hline schooling $\times$ farm & -0.020 & -1.58 \\
\hline schooling $\times$ mine or electric & $0.023^{*}$ & 1.93 \\
\hline schooling $\times$ manufacturing & 0.003 & 0.77 \\
\hline schooling $\times$ construction & -0.009 & -1.2 \\
\hline schooling $\times$ commerce & $0.068^{* * *}$ & 13.74 \\
\hline schooling $\times$ maquila & 0.004 & 0.42 \\
\hline schooling $\times$ fastlib & $-0.010^{* * *}$ & -4.81 \\
\hline schooling $\times$ slowlib & $-0.029 * * *$ & -13.79 \\
\hline
\end{tabular}


TABLE 3 Determinants of Log Monthly Earnings (continued)

\begin{tabular}{|l|l|l|}
\hline Variable & Coefficient & T-Ratio \\
\hline schooling $\times$ year 1999 & $-0.007^{* *}$ & -2.15 \\
\hline schooling $\times$ farm $\times$ year 1999 & $0.049^{* * *}$ & 3.52 \\
\hline schooling $\times$ mine or electric $\times$ year 1999 & 0.012 & 0.89 \\
\hline schooling $\times$ manufacturing $\times$ year 1999 & $0.013^{* * *}$ & 2.69 \\
\hline schooling $\times$ construction $\times$ year 1999 & $-0.018^{* *}$ & -2.18 \\
\hline schooling $\times$ commerce $\times$ year 1999 & $-0.049^{* * *}$ & -8.8 \\
\hline schooling $\times$ maquila $\times$ year 1999 & 0.010 & 0.89 \\
\hline Key Variables & & \\
\hline schooling $\times$ fastlib $\times$ year 1999 & $0.031 * * *$ & 10.52 \\
\hline schooling $\times$ slowlib $\times$ year 1999 & $0.048^{* * *}$ & 15.91 \\
\hline $\mathrm{R}^{2}=$ & \multicolumn{2}{|c|}{0.3614} \\
\hline $\mathrm{n}=$ & 203,550 \\
\hline$* *$, and $* * *$ denote significance at, respectively, the $10 \%, 5 \%$, and $1 \%$ levels
\end{tabular}




\section{References}

Burtless, G. 1995. International trade and the rise in earnings inequality. Journal of Economic Literature 33, no. 2: $800-816$.

Grossman, G.M. and E. Helpman. 1994. Endogenous innovation in the theory of growth. Journal of Economic Perspectives 8, no. 1: $23-44$.

Gruben, W.C. 2001. Was NAFTA behind Mexico’s high maquiladora growth? Economic and Financial Review, Federal Reserve Bank of Dallas, Third Quarter: $11-21$.

Hanson, G.H. and A. Harrison. 1999. Trade liberalization and wage inequality in Mexico. Industrial and Labor Relations Review 52, no. 2: $271-88$.

Lucas, R.E. 1988. On the mechanics of economic development. Journal of Monetary Economics 22, no. 1: 3 - 42. Mollick, A.V. 2008. Relative wages, labor supplies and trade in Mexican manufacturing: evidence from two samples. The Journal of International Trade \& Economic Development, forthcoming.

Revenga, A. 1997. Employment and Wage Effects of Trade Liberalization. Journal of Labor Economics 15, no. 3: $\mathrm{S} 20-\mathrm{S} 43$.

Robertson, R. 2000. Trade liberalization and wage inequality: lessons from the Mexican experience. World Economy 23, no. 6: $827-49$.

Robertson, R. 2004. Relative prices and wage inequality: evidence from Mexico. Journal of International Economics 64, no. 2: $387-409$.

Tybout, J.R. 2000. Manufacturing firms in developing countries: how well they do, and why? Journal of Economic Literature 38, no. 1: $11-44$.

Young, A. 1991. Learning by doing and the dynamic effects of international trade. Quarterly Journal of Economics 106, no. 2: $369-405$.

Zhiqiang, L. 2008. Foreign direct investment and technology spillovers: theory and evidence. Journal of

Development Economics 85, no. 2: 176-93 